\title{
Towards an analysis of "banking solutions" from the perspective of exporting companies in Brazil
}

\author{
Completed Research Paper
}

\author{
Mara Mataveli \\ University of La Rioja \\ maramataveli@gmail.com \\ Alfonso J. Gil \\ University of La Rioja \\ alfonso.gil@unirioja.es
}

\author{
Juan Carlos Ayala \\ University of La Rioja \\ juan-carlos.ayala@unirioja.es
}

\begin{abstract}
Banks in Brazil play a major role in the internationalization process of companies providing financial products and services. To examine this role, a model containing four concepts is analysed, these being "banking solutions" as the dependent variable and "relational capital", "bank efficiency" and "technologies in services" as independent variables. Through a variance-based structural equation model (SEM), the outcome of this analysis reveals that two independent variables ("relational capital" and "bank efficiency") have a significant and positive impact on the use of banking solutions. Also, from the export company vision it is found that "knowledge barriers" to export moderate the relationship between "bank efficiency" and "banking solutions". Guidelines for potential future research on the subject are provided.
\end{abstract}

Keywords: Banking solutions, relational capital, bank efficiency, banking technology

\section{Introduction}

In today's competitive environment, it is crucial that bank managers develop the ability to establish critical bank selection factors for segments of the market they wish to attract, to serve and expand their customer base. Rapid environmental changes will need continuing attention and emphasis on formulating bank marketing strategies on the part of managerial boards. Banks need to ensure that their services correspond to their clients' short- and longterm needs. The relationship between bank and client means more banking services and products used by the client and more profits to the banks.

Financial systems play a significant role in the economic development of countries; moreover, the variety of financial activities that differ between countries helps to explain a significant proportion of the growth of economies. Countries, according to their level of development, have different types of performance in their banking systems. For Braun (2003), in countries with low levels of financial development, the number of industries with more tangible assets is relatively larger in size and grows relatively faster than the number of industries with more intangible assets. In this context, this work has two objectives: 
- To analyse the influence of three key elements in the strategy of banks that provide financial services for export: bank relational capital, bank efficiency and technological aspects of services in the provision solutions of bank services, which can simply be defined as the various ways in which a bank can help a customer.

- To examine the moderation of export barriers, in particular the knowledge barrier in the export process. It is understood that barriers to exports are obstacles to the internationalization process of the company.

Through these two objectives, we intend first to determine from the perspective of exporting companies sources of competitive advantage for banks to provide assistance in export services; second, we examine the knowledge barrier as an element involved in the service relationship between exporters and banks. Thus, we argue that the bank can intervene in helping the company to solve export problems.

The empirical research is carried out among exporting companies in Brazil, an emerging country in which the banking system plays a key role in helping exports, aiding exporters in overcoming barriers to sell to other countries and boosting the level of internationalization of companies.

\section{Literature Review and Research Hypotheses}

At this point, we examine four constructs: banking solutions, bank efficiency, bank relational capital and banking technological services. Building on earlier investigations in the banking field, we develop eight hypotheses.

\subsection{Banking solutions}

In the broad sense, we define banking solutions as the various ways in which a bank can help a customer as a financial institution. Therefore, the "banking solutions" construct unites the concepts of banking services and products. The literature contains evidence of practitioners and academics using the words "products" and "services" in quite different ways. Economists discuss the term "products" as a measure of economic activity or output which can be broken down into two classes: tangible products, which are called goods, and intangible products, which are termed services (Akanavi, 2005a).

The importance of the financial services sector has been manifested in the recent fundamental changes that it has been experiencing. These include deregulation, increasing competition, the higher costs of developing new products, the rapid pace of technological changes and innovation and more demanding customers (Akamavi, 2005a).

When choosing a bank as financial support for its process of internationalization, a company analyses several aspects considered important in its decision making, such as: the prices charged, the types of loans and financing the bank offers to its customers, routes of access to credit, the conditions of contracts (such as term interest rates) and the provision of specific services, as well as other aspects such as its relationships with other banks, the level of expertise in the area of demand for credit, etc.

The literature contains studies analysing the differences between banks chosen by companies for their operation; these are studied according to dimensions such as origin (domestic or foreign), size (large or small), control (public or private), sector (retail, treasury, business and credit) and factors that define their role, strategy and performance (Cajueiro and Tabak, 2007). 
Most potential customers generally evaluate bank offerings. The selection of a bank with which to operate includes quite rudimentary factors, such as location, family relationship, recommendation, incentives offered, image and reputation, competitive interest rate, product range, service expectation, low fees/or charges, branch opening hours and home banking (Devlin and Gerrard, 2004).

Providing banking solutions to customers and offering financial services appropriate to customer needs have been considered important parts of bank strategy (Guyo and Adan, 2013) and they become a very important source of support for customer satisfaction (Zineldin, 1996). In this regard, it is noted that customers tend to be more interested in the functional quality of financial services than in the technical quality of the banks (Ulengin, 1998).

Furthermore, Mylonakis, Malliaris and Siomkos (1998) found relevant evidence in the selection criteria of the bank in relation to the quality of the products and services offered to the customers. For example, lack of appropriate products and services for small and medium enterprises is another important barrier to accessing financial services.

Reeves and Bednar (1996) argued that customer service appeared more important than services costs in evaluating and choosing between banks. To Elliot, Shatto and Singer (1996) aspects such as speed, price and access were found to be particularly important to companies in their choice criteria regarding banking.

According to Reinartz and Kumar (2003), the more products and services purchased by the customer, the longer the bank keeps the company that sells. In this sense, customer loyalty becomes part of bank sales tactics, together with the existence of a range of competitive products. Thus, products can be perceived differently when the company starts internationalizing and has to select between one or another bank as the primary or secondary option in banking operations (Devlin and Gerrard, 2005).

Based on the literature review, at this point we discuss the main reasons that lead the company to choose one or another bank for its operations in the international arena: (1) the financial costs and the size of the bank; (2) the geographical distance of the bank in relation to the company and the capillaries of the bank; (3) the technology used by the bank; (4) the bank's reputation, tradition, expertise in international trade; (5) financial and non-financial products offered by companies to foreign trade; (6) the perception of the efficiency, agility and safety of the bank; (7) the bank chosen by the controller company, supplier or importer; (8) the bank's flexibility in negotiations over financial support in the international arena (Mataveli, 2014).

In general, there are many different types of banking solutions. Many authors have pointed out different types of new tangible and intangible banking products (e.g. Akamavi, Thwaites and Burgess, 1999; Akamavi, 2005b). We include the following aspects as part of our model:

- Funding lines

- Credit limits

- Satisfaction of the controller company requirements

- Service rates

\subsection{Efficiency in banking services}

The concept of efficiency is not limited only to operational cost minimization but is also related to gaining new clients, managing costs and providing quality services (Grigoroudis, Tsitsiridi, and Zopounidis, 2013). In relation to this, financial institutions are re-examining how they currently perceive their customers' needs and developing the business plans needed to align them strategically to remain competitive (Abdullah, Suhaimi, Saban and Hamali, 2011). 
According to Acharya, Kagan and Lingam (2008), bank efficiency lies in providing a service mix related to the best practices of the company. These services can be identified as:

- Agility in service delivery

- Control exchange

- Agility in operations

- Flexibility in negotiations

- Information safety

These five aspects are related to quality management (Sánchez-Franco and MartínVelicia, 2011). Therefore, we propose the following hypothesis:

H1: From the perspective of the export companies, the perceived efficiency of bank service delivery has a positive effect on the use of banking solutions.

\subsection{The importance of relational capital in banking service strategy and bank efficiency}

As Dyer and Singh (1998) noted, the potential of a company to create competitive advantage depends not only on its resources but also on its relational assets, i.e. its relationships with other key firms, or its relational capital. Relational capital is defined as the set of all relationships - market relationships, power relationships and cooperation established between companies, institutions and people, which stem from a strong sense of belonging and a highly developed capacity for cooperation (Capelo and Faggian, 2005).

Regarding the banking sector, it is noted that intellectual capital is a source of performance (Wang, Lu and Wang, 2013). Specifically, we are referring to the relational capital of banks, which may indicate some particular sources of relational capital; for example, we have noted a bank's reputation as an important factor in the choice of decision makers to use the bank for its operations in international business (Ongena, Tümer-Alkan and Vermeer, 2011). In general, we can point out some sources of relational capital:

- Branch network

- Relationships with other banks

- Bank known abroad

- Tradition in international business

- Teams specialized in international trade

- Source reference in foreign trade

Therefore, we suggest the following hypotheses:

H2: From the perspective of the export companies, the bank's relational capital has a positive effect on the use of its banking solutions.

H3: From the perspective of the export companies, the bank's relational capital has a positive effect on bank efficiency. 


\subsection{The banking technology service, banking solutions and bank efficiency}

In recent years, the development of technology-based solutions in self-service formats has meant that banks have changed the way in which clients access many banking services (Bobbitt and Dabholkar, 2001). Innovative technologies may gain a competitive edge and achieve higher production efficiency (Acharya, Kagan and Lingam, 2008). For banks, the use of service technologies enables significant cost reductions while enhancing service efficiency and effectiveness (Cronin, 2003; Proença and Rodrigues, 2011). Both aspects are related to banking solutions and bank efficiency. Two items are noted regarding banking technology:

- Technology applied to banking services

- Internet solutions

Therefore, we develop the following hypotheses:

H4: From the perspective of the export companies, innovative technologies have a positive effect on banking solutions.

H5: From the perspective of the export companies, innovative technologies have a positive effect on bank efficiency.

\subsection{The moderating effect of export barriers}

Numerous investigations have pointed to the existence of barriers or limitations to international business activity (Leonidou, 1995a, b). Within these types of barriers, the lack of qualified personnel in international trade has been identified in the export area as one of the most critical problems (Leonidou, 2004). Companies that face difficulties in the export process derived, for example, from their own skills shortage in human capital, have differentiated perceptions of bank services or capabilities to solve their problems as they select banks that can help to solve these problems. Therefore, we note the following hypotheses:

H6: From the perspective of the export companies, export barriers moderate positively the relationship between a bank's relational capital and banking solutions.

H7: From the perspective of the export companies, export barriers moderate positively the relationship between bank efficiency and banking solutions.

H8: From the perspective of the export companies, export barriers moderate positively the relationship between banking technology services and banking solutions.

Figure 1 shows the overall model of analysis, summarizing the eight hypotheses proposed. 


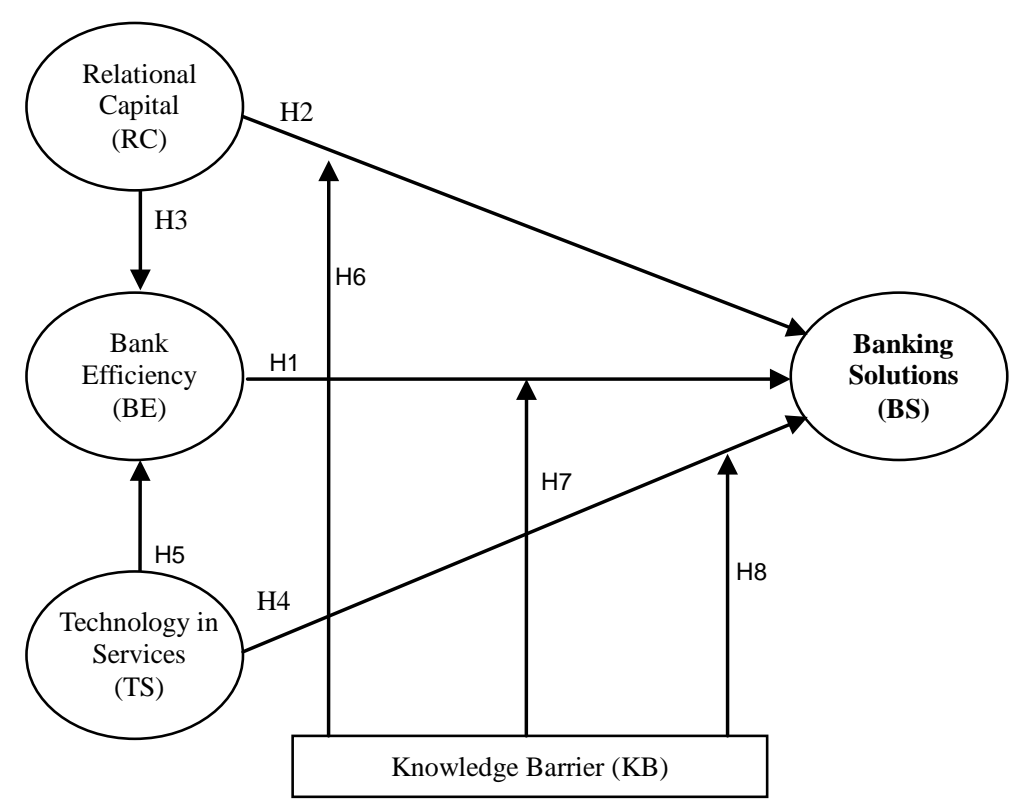

Figure 1: Research model

\section{Method}

\subsection{Sample and data collection}

To obtain the sample, we started with the Catalogue of Brazilian Exporters (CEB) database, which provides information regarding exports taken from the official records of the Secretary of Foreign Trade (SECEX), an internal area of the Ministry of Planning, Industry and Foreign Trade (MDIC) of Brazil. The final sample consisted of 318 companies: 76 agribusiness companies, 171 in the processing industry, 15 in mining and quarrying and 56 in the services sector. The sampling error is $\pm 4.6 \%$ with a $95 \%$ confidence level.

The instrument used for the collection of information was a self-administered questionnaire. The questionnaire design was based on the theoretical approaches shown in the first part of this work. The questionnaire was sent to the company, specifically to those responsible for the export business, as this was considered the most direct way to obtain data from the companies. Of the different procedures for collecting survey data (for example, personal interview, telephone interview, postal survey, self-administered questionnaire, network survey), we chose to conduct the survey in this study using the network approach through the Internet.

\subsection{Data analysis}

Our research model was tested using structural equation modelling, namely by means of the partial least squares (PLS) technique and utilizing the SMARTPLS software version 3.0 (Henseler, Ringle and Sarstedt, 2015). 


\section{Results}

\subsection{Measurement model analysis}

A factorial structure analysis was conducted using factor analysis of the primary components with Varimax rotation through SPSS version 22.0, which enabled us to prove the existence of four factors that coincide with constructs we termed: relational capital, bank efficiency, bank solutions and technology in services. The Kaiser-Meyer-Olkin (KMO) value of 0.879 indicates an adequate fit between the data and the factorial model. On the other hand, in the analysis of the total variance explained, four components were found to summarize $72.878 \%$ of total variability (the first component explaining $21.793 \%$, the second $20.238 \%$, the third $19.038 \%$ and the fourth $11.834 \%$ ). These four components correspond to the four constructs formed by reflective indicators.

We also analysed the reliability of the model. First, we analysed the standardized root mean square residual (SRMR) as a goodness of (model) fit measure for PLS-SEM. The value of 0.1 found is considered adequate for the model (Henseler et al., 2014; Hu and Bentler, 1998). The reliability of the indices must be analysed through their loadings $(\lambda)$. In our case, all factorial loadings, proved to be no less than 0.4 (Hair, Ringle and Sarstedt, 2011), explaining their inclusion in the model. Thus, a group of scales with a total of 17 items remains (see Table 1).

Table 1: Measurement model: cross-loadings

\begin{tabular}{|c|c|c|c|c|}
\hline Items & $\begin{array}{l}\text { Relational } \\
\text { Capital } \\
\text { (RC) }\end{array}$ & $\begin{array}{l}\text { Bank } \\
\text { Efficiency } \\
\text { (BE) }\end{array}$ & $\begin{array}{l}\text { Banking } \\
\text { Solutions } \\
\text { (BS) }\end{array}$ & $\begin{array}{l}\text { Technology } \\
\text { in Services } \\
\text { (TS) }\end{array}$ \\
\hline Relationships with other banks & .838 & & & \\
\hline Source reference in foreign trade & .833 & & & \\
\hline Branch network & .824 & & & \\
\hline Tradition in international business & .789 & & & \\
\hline Teams specialized in international trade & .773 & & & \\
\hline Bank known abroad & .745 & & & \\
\hline Agility in service delivery & & .884 & & \\
\hline Operational agility & & .868 & & \\
\hline Control exchange & & .838 & & \\
\hline Information safety & & .765 & & \\
\hline Flexibility in negotiations & & .761 & & \\
\hline Credit limits & & & .870 & \\
\hline Funding lines & & & .796 & \\
\hline Service rates & & & .758 & \\
\hline Satisfaction of controller company requirements & & & .661 & \\
\hline Internet solutions & & & & .961 \\
\hline Technology in bank services & & & & .941 \\
\hline
\end{tabular}

The reliability of the constructs was examined using Cronbach's alpha and the composite reliability index (CRI). The existence of convergent validity was confirmed by means of the average variance extracted (AVE). As shown in Table 2, either the Cronbach's alpha values or the CRI values surpass the critical value of 0.8 for all variables (Nunnally and Bernstein, 1994) and the values of AVE are above 0.5 (Fornell and Larcker, 1981). 
Table 2: Construct reliability and convergent validity

\begin{tabular}{lccc}
\hline & CR & Cronbach's $\alpha$ & AVE \\
\hline Relational capital & & & \\
Bank efficiency & 0.915 & 0.890 & 0.642 \\
Banking solutions & 0.914 & 0.881 & 0.680 \\
Technology in services & 0.856 & 0.779 & 0.601 \\
& 0.950 & 0.896 & 0.905 \\
\hline
\end{tabular}

The analysis of the measurement model involves verifying the existence of discriminant validity. In this regard, a new approach to assessing discriminant validity in variance-based SEM is the heterotrait-monotrait (HTMT) ratio of correlations proposed by Henseler, Ringle and Sarstedt (2015). Based on the criteria of $\mathrm{HTMT}_{0,85}$ discriminant validity issues for interconstruct correlations were not found (0,70 or less), as shown in Table 3.

Table 3: Discriminant validity

\begin{tabular}{lcccc}
\hline & Relational capital & Bank efficiency & Banking solutions & Technology in services \\
\hline & & & & \\
Relational capital & - & & & \\
Bank efficiency & 0.594 & 0.700 & - & - \\
Banking solutions & 0.538 & 0.510 & 0.359 & - \\
Technology in services & 0.525 & & & \\
\hline
\end{tabular}

\subsection{Structural model analysis}

To determine the statistical significance of the path coefficients of the model, a bootstrap resampling technique was employed with 5,000 subsamples (Hair, Ringle and Sarstedt, 2011). The structural model evaluates the magnitude and the significance of the relationship between the distinct variables. It is a matter of analysing the explained variance of the endogenous variables $\left(R^{2}\right)$, the path coefficients or standardized regression weights $(ß)$ and the respective levels of significance, through the Stone-Geisser $\left(\mathrm{Q}^{2}\right)$ test (see Figure 2).

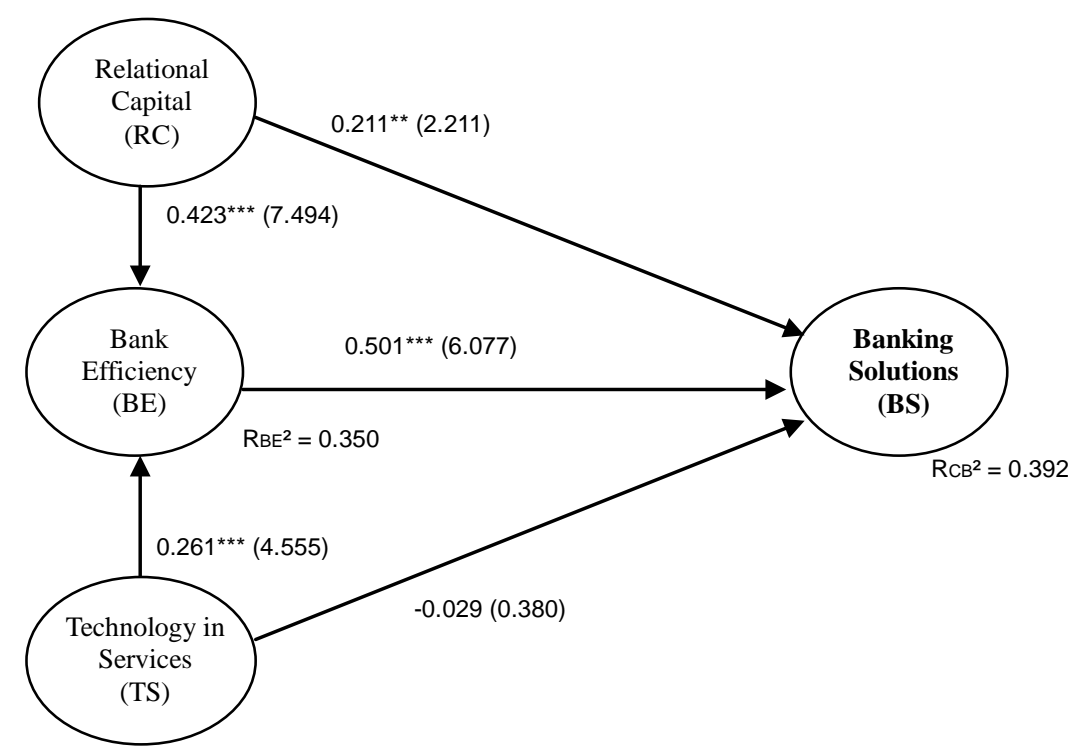

Figure 2: Structural model 
The following relationships were found to be significant: (1) bank efficiency and banking solutions ( $\left(=0.501^{* * *}\right)$; (2) relational capital and banking solutions ( $\left(=0.211^{* *}\right.$ ); (3) relational capital and bank efficiency $\left(\Omega=0.423^{* * *}\right)$; (4) technology in services and banking solutions ( $(=-0.029)$; $(5)$ technology in services and banking efficiency $\left(~\left(=0.261^{* * *}\right)\right.$ (see Table 4). Thus, H1, H2, H3 and H5 are validated.

Table 4: Structural model results (baseline model)

\begin{tabular}{lcccc}
\hline \multicolumn{5}{c}{$\mathrm{RES}^{2}=0.350$} \\
$\mathrm{RCB}^{2}=0.392$
\end{tabular}

${ }^{*} \mathrm{p}<0,05 ; * * \mathrm{p}<0,01 ; * * * \mathrm{p}<0,001$; not significant (based on t (499), one-tailed test); $\mathrm{t}(0,05 ; 499)=1,64791345, \mathrm{t}(0,01 ; 499)=$ 2,333843952; $\mathrm{t}(0,001 ; 499)=3,106644601$

Tables 5 and 6 show the moderation processes in the proposed relationships. Table 5 indicates the relationship for relational capital and banking solutions.

Table 5: Structural model results with moderation of the knowledge barrier in the relationship between relational capital and banking solutions

\begin{tabular}{|c|c|c|c|}
\hline & $\begin{aligned} \mathrm{RBS}^{2} & =0.414 \\
\mathrm{RBE}^{2} & =0.350\end{aligned}$ & & \\
\hline Hypothesis & Path coefficients & t-value (bootstrap) & Support \\
\hline $\mathrm{H} 1: \mathrm{BE} \rightarrow \mathrm{BS}$ & $0.433 * * *$ & 5.370 & Yes \\
\hline $\mathrm{H} 2: \mathrm{RC} \rightarrow \mathrm{BE}$ & $0.215^{* *}$ & 2.842 & Yes \\
\hline H3: $\mathrm{RC} \rightarrow \mathrm{BE}$ & $0.423 * * *$ & 7.726 & Yes \\
\hline $\mathrm{H} 4: \mathrm{TS} \rightarrow \mathrm{BS}$ & 0.061 & 0.660 & No \\
\hline H5: $\mathrm{TS} \rightarrow \mathrm{BE}$ & $0.261 * * *$ & 4.541 & Yes \\
\hline H6: RCxKB $\rightarrow$ BS & $0.091 *$ & 1.732 & Yes \\
\hline
\end{tabular}

${ }^{*} \mathrm{p}<0,05 ;{ }^{* *} \mathrm{p}<0,01 ;{ }^{* * *} \mathrm{p}<0,001$; not significant (based on $\mathrm{t}(499)$, one-tailed test); $\mathrm{t}(0,05 ; 499)=1,64791345, \mathrm{t}(0,01 ; 499)=$ 2,333843952; $\mathrm{t}(0,001 ; 499)=3,106644601$

As shown in Table 5, hypothesis H6 is confirmed and the knowledge barrier moderates the relationship between relational capital and banking solutions.

Table 6 notes the relationship for relational capital and banking solutions. 
Table 6: Structural model results with moderation of the knowledge barrier in the relationship between bank efficiency and banking solutions

\begin{tabular}{llcc}
\hline & $\begin{array}{l}\mathrm{RBS}^{2}=0.449 \\
\mathrm{RBE}^{2}=0.350\end{array}$ & \\
\hline Hypothesis & Path coefficients & t-value (bootstrap) & Support \\
\hline & & & \\
$\mathrm{H} 1: \mathrm{BE} \rightarrow \mathrm{BS}$ & $0.415^{* * *}$ & 5.203 & Yes \\
$\mathrm{H} 2 \mathrm{RC} \rightarrow \mathrm{BE}$ & $0.201^{* *}$ & 2.789 & Yes \\
$\mathrm{H} 3: \mathrm{RC} \rightarrow \mathrm{BE}$ & $0.423^{* * *}$ & 7.674 & Yes \\
$\mathrm{H} 4 \mathrm{TS} \rightarrow \mathrm{BS}$ & 0.068 & 0.778 & No \\
$\mathrm{H} 5: \mathrm{TS} \rightarrow \mathrm{BE}$ & $0.261^{* * *}$ & 4.654 & Yes \\
$\mathrm{H} 7: \mathrm{BExKB} \rightarrow \mathrm{BS}$ & $0.197^{* * *}$ & 3.909 & \\
& & &
\end{tabular}

${ }^{*} \mathrm{p}<0,05 ;{ }^{* *} \mathrm{p}<0,01 ;{ }^{* * *} \mathrm{p}<0,001$; not significant (based on $\mathrm{t}(499)$, one-tailed test); $\mathrm{t}(0,05 ; 499)=1,64791345, \mathrm{t}(0,01 ; 499)=$ 2,333843952; $\mathrm{t}(0,001 ; 499)=3,106644601$

As illustrated in Table 6, the hypothesis $\mathrm{H7}$ is confirmed and the knowledge barrier moderates the relationship between bank efficiency and banking solutions. The hypothesis 8 is not contrasted because the relationship between technologies in services and bank solutions is not significant.

\section{Conclusions, contributions and future research}

This paper has two objectives. First, in line with other works (Ladhari, Ladhari and Morales, 2011), it analyses the perceptions of Brazil's export companies regarding the competitive advantage of banks operating in international trade. From the perspective of the export companies, it was found that competitive advantage - with regard to the use of banking solutions in relation to bank efficiency - derives from agility and flexibility in providing products and services. But in turn, bank efficiency is related to the relational capital of the bank and the application of new technologies in banking services.

Second, we analyse the moderation effects (Henseler and Fassot, 2010) of export barriers in the relationship between all the proposed constructs in the model. As affirmed in the hypotheses, there is significant moderation from the barrier "human resources", referring to workers who are low skilled in foreign trade. The significance of this moderation effect indicates a different perception regarding banking transactions related to business problems in the international arena. This results from the strong intervention of banks in the process of internationalization of companies in Brazil.

This work contributes to research and banking practice in two respects. The first is that it indicates the importance of bank efficiency as a key characteristic in banking business and furthermore that to increase efficiency, it is necessary to invest in new technologies (Jenkins, 2007). Second, we find that there is a delay in the export barrier related to the skills of human resources, which points to this problem moderating the relationship between clients and banks.

Based on the above, we can point to two future research lines. The first is to study other barriers to companies' internationalization, e.g. cultural or credit barriers. The second is to analyse the involvement of banks in the process of the internationalization of companies in Brazil, specifically in relation to the financial and non-financial mechanisms that help the enterprises to overcome barriers to exports.

This paper has certain limitations, one of which is that it is a study developed on the basis of clients' perceptions of banking services. Future research might analyse competitive advantage from the banks' perspective and explore the quality of services offered by banks. 


\section{References}

Abdullah, F., Suhaimi, R., Saban, G., \& Hamali, J. (2011). Bank service quality (BSQ) index. International Journal of Quality \& Reliability Management, 28 (5), 542-555.

Acharya, R. N., Kagan, A., \& Lingam, S. R. (2008). Online banking applications and community bank performance. The International Journal of Bank Marketing, 26 (6), 418-439.

Akamavi, R. K., Thwaites, D., \& Burgess, T. F. (1999). Incorporating customer-organisation capabilities in the new product development process: issues in the financial services sector. Part 1. Journal of Financial Services Marketing, 3 (4), 359-372.

Akamavi, R. K. (2005a). A research agenda for investigation of product innovation in the financial services sector. Journal of Services Marketing, 19 (6), 359-378.

Akamavi, R. K. (2005b). Re-engineering service quality process mapping: e-banking process. International Journal of Bank Marketing, 23 (1), 28-53.

Bobbitt, L., \& Dabholkar, P. (2001). Integrating attitudinal theories to understand and predict use to technology-based self-service. The internet as an illustration. International Journal of Service Industry Management, 12 (5), 423-450.

Braun, M. (2003). Financial contractability and asset hardness. Mimeo. Boston: Harvard University.

Cajueiro, D. O., \& Tabak, B. M. (2007). The role of banks in the Brazilian interbank market: does bank type matter? Working Paper Series, n. 130, Banco Central del Brasil.

Capello, R., \& Faggian, A. (2005). Collective learning and relational capital in local innovation processes. Regional Studies, 39 (1), 75-87.

Cronin, J. J. Jr (2003). Looking back to see forward in services marketing: some ideas to consider. Managing Service Quality, 13 (5), 332-337.

Devlin, J., \& Gerrard, P. (2005). A study of customer choice criteria for multiple bank users. Journal of Retailing and Consumer Services, 12, 297-306.

Dyer J., \& Singh, H. (1998). The relational view: cooperative strategy and sources of interorganizational competitive strategy. Academy of Management Review, 23, 660679.

Elliot, M. B., Shatto, D., \& Singer, C. (1996). Three customer values are key to marketing success. Journal of Retail Banking Services 18 (1), 1-7.

Fornell, C., \& Larcker, D. F. (1981). Evaluating structural equation models with unobservable variables and measurement error. Journal of Marketing Research, 18, 39-50.

Grigoroudis, E., Tsitsiridi, E., \& Zopounidis, C. (2013). Linking customer satisfaction, employee appraisal, and business performance: an evaluation methodology in the banking sector. Annals of Operations Research, 20, 5-27.

Guyo, W., \& Adan, N. (2013). The determinants of retail consumer choice of Islamic banking in Kenya. International Journal of Arts and Entrepreneurship, 1 (2), 1-12.

Hair, J. F., Ringle, C. M., \& Sarstedt, M. (2011). PLS-SEM: Indeed a silver bullet. Journal of Marketing Theory and Practice, 19 (2), 137-149.

Henseler, J., Ringle, C. M., \& Sarstedt, M. (2015). A new criterion for assessing discriminant validity in variance-base structural equation modeling. Journal of the Academy of Marketing Science, 43, 115-135.

Henseler, J., Dijkstra, T. K., Sarstedt, M., Ringle, C. M., Diamantopoulos, A., Straub, D. W., Ketchen, D. J., Hair, J. F., Hult, G. T. M., \& Calantone, R. J. (2014). Common beliefs and reality about Partial Least Squares: Comments on Rönkkö \& Evermann (2013). Organizational Research Methods, 17 (2), 182-209.

Henseler, J., \& Fassott, G. (2010). Testing moderating effects in PLS path models: An illustration of available procedures. In: Esposito Vinzi, V.; Chin, W. W.; Henseler, J.; 
\& Wang, H. (Eds.): Handbook of Partial Least Squares. Berlin: Springer, pp. 713-735.

Hu, L., \& Bentler, P. M. (1998). Fit indices in covariance structure modeling: Sensitivity to underparameterized model misspecification. Psychological Methods, 3 (4), 424-453.

Jenkins, H. (2007). Adopting internet banking services in a small island state: assurance of bank service quality. Managing Service Quality: An International Journal, 17 (5), 523-537.

Ladhari, R., Ladhari, I., \& Morales, M. (2011). Bank service quality: comparing Canadian and Tunisian customer perceptions. International Journal of Bank Marketing, 29 (3), 224-246.

Leonidou, L. C. (1995a). Empirical research on export barriers: review, assessment, and synthesis. Journal of International Management, 3 (1), 29-43.

Leonidou, L. C. (1995b). Export barriers: non-exporters' perceptions. International Marketing Review, 12 (1), 4-25.

Leonidou, L. C. (2004). An analysis of the barriers hindering small business export development. Journal of Small Business Management, 42 (3), 279-302.

Mataveli, M. (2014). La internacionalización de las empresas en Brasil. La elección de un banco para superar barreras a la exportación y dinamizar el nivel de internacionalización de la empresa. Doctoral thesis. University of La Rioja, Spain.

Mylonakis, J., Malliaris, P., \& Siomkos, G. (1998). Marketing-driven factors influencing savers in the Hellenic bank market. Journal of Applied Business Research, 14(2), 109116.

Nunnally, J. C., \& Bernstein, I. H. (1994). Psychometric theory. Nueva York: McGraw-Hill.

Ongena, S., Tümer-Alkan, G., \& Vermeer, B. (2011). Corporate choice of banks: decision factors, decision maker and decision process - first evidence. Journal of Corporate Finance, 17, 326-351.

Proença, J. P., \& Rodrigues, M. A. (2011). A comparison of users and non-users of banking selfservice technology in Portugal. Managing Service Quality: An International Journal, 21 (2), 192-210.

Reeves, C. A., \& Bednar, D. A. (1996). Keys to market success - a response and another view. Journal of Retail Banking Services, 18 (4), 33-40.

Reinartz, W. J., \& Kumar, V. (2003). The impact of customer relationship characteristics on profitable lifetime duration. Journal of Marketing, 67 (1), 77-99.

Sánchez-Franco, M. J., \& Martín-Velicia, F. A. (2011). The interaction effects of ego involvement on the relationships between aesthetics, usability and commitment. Online Information Review, 35 (2), 194-216.

Ulengin, B. (1998). Using hierarchical information integration to examine customer preferences in banking. International Journal of Bank Marketing, 16, 202-210.

Wang, W. K., Lu, W. M., \& Wang, Y. H. (2013). The relationship between bank performance and intellectual capital in East Asia. Quality and Quantity, 47, 1041-1062.

Zineldin, M. (1996). Bank strategic positioning and some determinants of bank selection. International Journal of Bank Marketing, 14 (6), 12-22. 